\title{
The importance of context in store forecasting: The site visit in retail location decision-making
}

Received (in revised form): 5th December, 2007

\section{Steve Wood}

is a lecturer at the School of Management, University of Surrey and an Advanced Institute of Management (AIM) Scholar. Before re-entering academia in 2005 , he worked as a location analyst for Tesco Plc.

\section{Andrew Tasker}

is Director of Optimum Locations, an independent retail location analysis consultancy. He previously led the Location Planning function at Sainsbury's for nearly 15 years. He is a founder member of the Demographics User Group and a member of the Marketing Society and Market Research Society.

Keywords store location, site visit, store forecasting, knowledge management, location planning

\begin{abstract}
The aim of this paper is to investigate how practical store location decision-making balances formal modelling with the less well-studied informal qualitative inputs. By using case studies from one major UK food retailer, we find that informal knowledge has to be considered seriously alongside quantitative models despite the inclusion of such knowledge often proving challenging. In particular, the site visit has a key role in contextualising factors that are difficult to represent in formal 'modelled' data, and in calibrating the inputs to models that are becoming increasingly advanced. We conclude that conceptualising the role of knowledge management in retail store decision-making has been under-theorised but can offer a key to advancing our understanding of this process still further. Journal of Targeting, Measurement and Analysis for Marketing (2008) 16, 139-155. doi:10.1057/jt.2008.3;
\end{abstract} published online 10 March 2008

\section{INTRODUCTION}

Readers of geographical-, marketing- and service industry-related journals will be impressed by the advances made in the discipline of retail store location forecasting and decision-making over the past two decades. ${ }^{1}$ The increased development of computing power, aligned with ever-increasing real estate values (and therefore the huge sunk costs of store development $)^{2}$ has led to an environment where leading retailers are increasingly willing to invest capital in improved accuracy in forecasting, which thereby reduces investment risk. As Cohen and Applebaum ${ }^{3}$ described it back in 1960, 'Profit

Correspondence: Steve Wood, School of Management,

University of Surrey, Guildford, Surrey GU2 7XH, UK.

Tel: + 44 (0)1483 686344;

Fax: + $44(0) 1483686346$;

E-mail: sm.wood@surrey.ac.uk is tied to sales. Therefore, a site evaluation begins with an estimate of sales that can reasonably be expected' (p. 1).

While degrees of retail investment may vary markedly between a $2,000 \mathrm{ft}^{2}$ convenience store and a large $120,000 \mathrm{ft}^{2}$ hypermarket, new store construction represents a huge capital outlay to the operator. ${ }^{4}$ To underline the critical nature of such decision-making in a contemporary perspective our industry experience suggests that a 10 per cent variation in a sales forecast from reality for a medium-sized grocery superstore could change the affordable bid for a site by about $£ 5 \mathrm{~m}$. Given the highly competitive nature of land sale auctions for strategically located sites, this could potentially mean losing the site to a competitor, or conversely, leaving the retailer with an unprofitable store. Unsurprisingly, a profitable niche has emerged for the leading store location 
companies such as MapInfo, Experian and CACI that act in a consulting capacity to retailers, having developed extensive expertise in store forecasting and assessment techniques. ${ }^{5}$

While recognising the tremendous benefit that highly quantitative, technological and data-rich methods can have for 'in-office' decision-support, in this paper we contend that this must not be to the detriment of thorough and methodological investigations at the level of the site visit. As much organisation theory has underlined, there is a difference between theoretical work routine and actual 'work in practice'. ${ }^{6-8}$ First, data and insight gleaned while physically 'on location' allows the calibration of data inputs that feed into spatial interaction models. Furthermore, site and catchment examination may permit the identification of factors that are not necessarily revealed in data purchased from consultancies or acquired from the Census. Secondly, insights gleaned when on-site may often be difficult to represent in many of the 'in office' highly quantitative models, thereby presenting challenges in decision-making. This underlines the continuing conflict within Management Science more broadly between tacit knowledge that is 'deeply rooted in action, commitment, and involvement in context' and therefore 'hard to formalise and communicate', ${ }^{9}$ and codified knowledge 'that is transmittable in formal, systematic language' (Nonaka, ${ }^{10}$ p. 16) and thus more easily introduced into quantitative modelling solutions. Hence, this research aims to unpack the information that emerges from this critical stage of the assessment process and links with the knowledge management literature concerning how such insights can be incorporated into decision-making processes.

In this paper, first we briefly review the development of decision-support systems over the past two decades and the implications that these have had for site forecasting. Secondly, we examine how the role of the site visit has been assessed in the historical site selection literature and review its limited coverage in more contemporary accounts. Thirdly, we look at two case studies focusing on new site forecasting at a major UK food retailer. By doing so we examine the role of the site visit and the types of knowledge and findings that it can reveal. In the subsequent fourth and fifth sections, we review how these knowledges are successfully integrated (or not) into the formalised forecasting process and the broader challenges that this entails. Finally, we end with some conclusions and managerial implications.

\section{THE BACKGROUND TO DECISION-SUPPORT SYSTEM SOPHISTICATION}

Hernandez et al. ${ }^{11}$ distinguish between a number of different hierarchies of retail location planning and decision-making, ranging from 'strategic', which is concerned with the macro scale issues of a retailer's locational strategy and typical positioning, and at the other extreme, 'tactical', which focuses on issues of local marketing and promotion at the micro scale. In the middle of the scale is the issue of 'monadic' decisionmaking, concerning individual outlets, whether via new openings, closures or refits. It is this final category with which we are concerned in this paper and the tools that retailers use to aid in store forecasting (see Table 1).

Established sales forecasting decision-support include simply utilising experience ${ }^{12}$ and checklists $^{13}$ on field visits, as well as analogue models. ${ }^{14}$ As data became easier to collect and sophistication increased, there were increasingly complex attempts at multiple regression modelling which saw considerable returns in terms of increased sales forecasting accuracy. ${ }^{15}$ At the extremes, there were also some early efforts at utilising the theoretical contribution of spatial interaction modelling, though numerous studies during the pre-computer age found it less than successful largely owing to the considerable quantitative demands of the technique. ${ }^{16}$

Wrigley regards the late 1980s as the 'golden age' for store location analysis. ${ }^{17}$ Similarly, Moutinho et al. ${ }^{18}$ identify the decade as a landmark period for the sophistication of site assessment procedures, characterised by the abandonment of 'the intuitive approach to location decision-making' (p. 205). They chart 
Table 1: Principal site evaluation tools

\begin{tabular}{|c|c|c|}
\hline Technique & Details & $\begin{array}{l}\text { Technological } \\
\text { and data input }\end{array}$ \\
\hline Experience/experimental & $\begin{array}{l}\text { 'Rule of thumb' procedures often employed 'on site' where the benefits of } \\
\text { experience, observation and intuition drive decision-making. }\end{array}$ & Low \\
\hline Checklist & $\begin{array}{l}\text { Procedure to systematically evaluate the value of (and between) site(s) on the } \\
\text { basis of a number of established variables. }\end{array}$ & \\
\hline Ratio & $\begin{array}{l}\text { Assumes that if a retailer has a given share of competing floorspace in an area it } \\
\text { will achieve a proportionate share of total available sales. }\end{array}$ & \\
\hline Analogues & $\begin{array}{l}\text { Existing store (or stores) similar to the site are compared to it to tailor turnover } \\
\text { expectations. }\end{array}$ & \\
\hline Multiple regression & $\begin{array}{l}\text { Attempts to define a correlation between store sales and variables within the } \\
\text { catchment that influence performance. }\end{array}$ & \\
\hline $\begin{array}{l}\text { Geographical information } \\
\text { systems (GIS) }\end{array}$ & $\begin{array}{l}\text { Spatial representation of geodemographic and retail data that is based on } \\
\text { digitalised cartography and draws on relational databases. }\end{array}$ & \\
\hline $\begin{array}{l}\text { Spatial interaction } \\
\text { modeling }\end{array}$ & $\begin{array}{l}\text { Derived from Newtonian laws of physics based on the relationship between } \\
\text { store attractiveness and distance from consumers. May operate 'within' a GIS. }\end{array}$ & \\
\hline Neural networks & $\begin{array}{l}\text { Computer-based models explicitly represent the neural and synaptic activity of } \\
\text { the biological brain. }\end{array}$ & High \\
\hline
\end{tabular}

the development of publicly available geodemographic databases in combination with increases in computing power and more technical assessment techniques. This evolution was undeniably facilitated by the emergence of geographical information systems (GIS) that were labelled in the early 1990s as a 'paradigm shift in cartography'. ${ }^{19}$ This spatial representation of geo-demographic and retail data is particularly powerful and based 'on a crossing of digitalized cartography in addition to relational databases' (Mendes and Themido, ${ }^{20}$ p. 14) which ultimately allows non-GIS specialists to quickly interpret and understand complex geo-demographic patterns and trends. ${ }^{21}$ The development of GIS effectively allowed the potential inherent in spatial interaction models to become a practical forecasting reality. ${ }^{22}$

As the technology to manipulate and analyse huge amounts of data has developed, the potential of neural networks has been discussed in the literature. This technique, while still in its infancy, moves into the domain of artificial intelligence by explicitly representing the neural activity of the human brain. ${ }^{23}$ Despite the emphasis that this method has received by academics, ${ }^{24}$ its application in practical forecasting has been more limited - 'the authors are not aware of any blue-chip businesses that are currently using this technology for retail planning' (Birkin, et al., ${ }^{25}$ p. 144).

The clear thrust of recent academic literature concerning store location assessment has been 'to tackle the uncertainties by developing more sophisticated models in which they seek to incorporate all variables and interactions' (Dijst et al., ${ }^{26}$ p. 1333). However, with many of these progressive developments, it is easy to forget that retail location management is essentially a contextspecific practice where retail strategy, planning regulation, site availability and consumer behaviour intersect. Location planning is therefore concerned with a wealth of external factors that affect proposals over and above the simple identification of the most efficient location for a store in relation to its catchment. For example, UK grocery retailers have had to become increasingly flexible in location and format development, partly driven by government planning legislation, leading to huge diversity in their store portfolios. ${ }^{27,28}$ Indeed, Poole et al. ${ }^{29}$ underline the dynamism with this situation, noting that 'the minimum catchment population needed for store viability has declined over the last decade, meaning that more areas have potential for further exploitation 
(especially by new retail formats)' (pp. 2130-2131). Given such variation and innovation across a variety of locations, arguably 'off the shelf' in-office modelling packages may not provide the single 'solution' to forecasting challenges; not least in the absence of numerous analogous stores within the existing store estates of retailers which can act as benchmarks of performance when forecasting sales.

\section{THE ROLE OF THE SITE VISIT IN STORE LOCATION DECISION-MAKING}

Research that has analysed retailer's employment of site assessment approaches has uncovered the utilisation of a huge variation of techniques but has also noted that there are still many operators for whom 'location planning is often undertaken on the basis of subjective rules of thumb and a degree of opportunism relating to the availability of individual sites' (Pioch and Byrom, ${ }^{30}$ p. 223), 'intuition' 31 or 'common sense'. 32 Hence, the site assessment process is a blend of 'art and science', ${ }^{33}$ though the majority of the literature portrays it more as a complex office-based data manipulation and modelling challenge.

Even where complex quantitative modelling is employed, there is still a need to visit the store location and surrounding catchment in order to assess the nature of that location and its place in the context of wider competitive influences, population, transport networks, as well as the quality of unit or store site itself. From a practitioner standpoint, it is notable that the academic literature continues to focus on largely theoretical, context-unspecific and unapplied scenarios in technique development rather than practical usage within the organisational context of the firm. ${ }^{34-39}$ Notably, Birkin et al. ${ }^{40}$ do not discuss the site visit, while Rogers' practically focused 1992 text $^{41}$ makes only fleeting references to this part of the process. For Clarke et al. ${ }^{42}$ there is therefore a tendency for research to 'either ignore or underplay retailers' intuitive judgement in the location decision-making process' (p. 267).

In part, the importance of the site visit derives from the micro-scale nature of the site and the advantages and impediments to success that it offers. Fenwick ${ }^{43}$ usefully distinguishes between locational advantages that 'depend upon the characteristics of the surrounding population and competition' and site advantages that arise from its 'peculiar characteristics' and 'range from accessibility, store size, layout, proximity of competition etc' (p. 3). Similarly, Brown ${ }^{44}$ suggests that despite the recent advances in location modelling and GIS, the outcome of locational decisions ultimately rests on micro-scale considerations and the precise location within a catchment - exactly where the site visit is essential. Meanwhile, recent work in modelling store closures conceded that 'we see that there are a number of location specific characteristics that may be of equal or greater importance than broader regional effects' (Shields and Kures, ${ }^{45}$ p. 267).

When forecasting sales, analysts deal with issues that are not binary but relative and centre on issues of understanding and context as much as data processing. Indeed, recent research ${ }^{46}$ has suggested consumers' behaviour is becoming more difficult to forecast with changes in household composition and responsibilities: 'consumer choice is socially embedded within households' increasingly complex everyday lives, with shopping "fitted in" around people's other responsibilities and commitments (childcare, work, leisure, etc)' (p. 59). It is essential to note that accessibility is not simply the outcome of the geography of the catchment, but also 'socially constructed notions of value, price, and quality' (Jackson et al., ${ }^{47}$ p. 61). It is the context-specific, geographical, cultural and political nature of the catchment (and the interactions between them) that has to be understood 'on the ground' as well as represented in data. ${ }^{48}$

Significantly for this paper, Wood and Browne ${ }^{49}$ argue that there are considerably different site assessment challenges in the forecasting of smaller stores selling low order goods due to their limited catchments that are inherently more difficult to model. They find that the data upon which forecasting models for convenience stores are based is likely to be less rigorous at a finer spatial scale of the micro environment where small 
changes in store visibility or proximity to roads or pedestrian flows may result in disproportionate affects on sales performance. This places a greater reliance on visiting the site in-person to experience it from a consumer's perspective rather than rely predominantly on data manipulated in the office via modelling. In contrast, larger stores have extensive catchments so are less sensitive to the spatial scale of data and more likely to be accurately forecast using techniques such as the spatial interaction model.

Given our argument that the essential role of situational context is being largely overlooked in the academic literature on store forecasting, what should the site visit actually entail and what can it achieve? Table 2 presents a summary of this literature, coupled with insights from the industry experience of both authors. It details the role of the site visit across three spatial scales of analysis, coupled with the sources of information for assisting decision-making that it can provide. In addition to analysis at various spatial scales, it is also essential to consider the time and day of the week the site visit is scheduled. Obviously viewing events such as the lunchtime trade in town centres can provide a rather over-optimistic representation of the potential in a catchment.

The situational knowledge produced on the site visit is well known within successful retailers to partially fill gaps in knowledge that can improve accuracy for forecasting. At a recent analyst roundtable event organised by Estates Gazette, Mark Chivers, Head of Strategy Development \& Research at Boots, commented:

It's easy to sit in Nottingham and twiddle with the GIS and think you can do a sales forecast for Hale in Cornwall.You go, and then you discover that the people there are different. ${ }^{56}$

Interestingly, within the industry, commentators can be quite lucid about the limitations of inoffice modelling and therefore the requirement for contextual data from the field:

Many factors that are not easily measurable (e.g. operations) affect store performance, while other factors (e.g. visibility ratings) can only be measured in an imperfect manner. It is important to note that retail models cannot directly model situations that aren't present in a database of stores that already exist. (Wolfe, ${ }^{57}$ p. 9)

Meanwhile, it is also clear that commercially available catchment data can have its limitations, which means calibrating via data collection at site visits - an issue largely missing from recent store location research:

While commercial geocoders become more accurate with every release, it is not uncommon to find that - due to factors such as address errors - the geocoder returns a location that is 14 mile, 12 mile or even several miles from the true location. Yet, many companies continue to make multi-million dollar decisions from points entered into a geocoder without any additional verification (Wolfe, ${ }^{58}$

pp. 9-10)

\section{The challenge of knowledge integration in site evaluation}

Some management-based research has begun to recognise the challenges of integrating qualitative insights into the decision-making process. There have been some useful contributions reported in the site assessment literature, primarily from Clarke and colleagues in analysing the role of intuition within store location decision-making. While this specific research does not consider the site visit per se, it does use cognitive mapping to analyse differing conceptions regarding what factors underpin successful store locations between the different actors in the development decision, whether site research specialists or senior management. ${ }^{59}$ Especially interesting was the finding that senior managers in the decisionmaking process place a 'greater reliance on key constructs and a higher proportion of non-factual information... benchmarking their thoughts against their own experiences and outcomes of previous corporate decisions' (Clarke and Mackaness, ${ }^{60}$ p. 166). Latter research by the same group $^{61}$ devised a tool to select analogue stores by integrating the 'soft' insights of executives. While such analysis is undeniably interesting, it does not reveal how qualitative insights taken 'in the field' can be integrated into modelling or justified in the decision-making process. Some older literature has experimented with introducing intuition 
Table 2: Role of the site visit

Catchment
Inventory of the competition

Study consumers through surveys

Check residential areas

Site location

Accessibility of the site and throughout the catchment

Visibility of site

Traffic flows around site

Pedestrian flows around the site

Crime check

Site development scheme Appraise the shape of the store and car park
Assess competition specifically for:
(a) Size of selling area
(b) No. of assistants
(c) No. of checkouts
(d) Range of goods and services
(e) Price policy
(f) Opening hours
(g) Additional services (eg petrol station, toilets, café)
(h) Car parking (no. of spaces and configuration)
(i) Condition of store (recently refitted?)
(j) Drivetimes to and from site in question
(k) Location of competitors (standalone/mall/district center/retail parks, etc)
(l) Nature of store performance (eg basket or trolley trade?)
(m) Observe core customers (eg age, affluence)

Customer 'spotting' surveys to understand:

(a) Current customer shopping patterns

(b) Perceptions of retail image of competitors and current stores in portfolio

(c) To study areas of under-penetration

Visit residential areas to review:

(a) Nature of residential catchment compared to available data (if any)

(b) Any areas of new housing development that may affect forecasts

(c) Cultural geography of the catchment. Understand divisions between areas that may not be well represented in traditional data sets

(a) Ease of access and egress in terms of to the site and within the site itself (eg car park layout)

(b) Role and perception of 'trade barriers' for the customers (eg rivers, motorways, topography, etc)

(a) View from pedestrian walkways

(b) View from immediate road on entry and egress

(c) View from major adjacent roads

(a) Measure flows throughout different types of day

(b) Check road speeds and for one-way streets especially for model calibration if using spatial interaction models

(c) Check for any new roads not recorded in current data or models

Measure flows throughout different types of day

Examine area around the site for evidence of crime, litter, etc

Appraise the scheme for:

(a) Size and shape of store relative to the scheme plans

(b) Review the suitability of the car park shape and size relative to the scheme (esp. in terms of access)

(c) Review the scheme critically -can it be improved?

Sources: Based on an extensive review of the literature (especially: Applebaum, ${ }^{50,51}$ Bowlby et al., ${ }^{52}$ Cohen and Applebaum, ${ }^{53}$ Rogers $^{54}$ and Snow and Scott ${ }^{55}$ ) as well as industry experience

within marketing forecasting models, concluding that if managers and modellers could identify the informational basis for exceptions to the model, the model refinement process could be improved. ${ }^{62}$ However, as our paper underlines, the art of site forecasting is understanding the flexibility and variations required for different scenarios.

Clearly then, '(m)any site factors are difficult to quantify but can have a dramatic effect on store sales' (Rogers, ${ }^{63}$ p. 207), but what improvements 
can their consideration contribute to increasing accuracy of the forecasting process? Furthermore, how can the knowledges that they produce be integrated into the forecasting process? We now present two case studies based on store forecasting at J Sainsbury plc, a major UK food retailer, that seek to offer some perspectives on the contribution of the site visit and its integration within the wider forecasting process.

\section{CASE STUDY 1: FORECASTING A NEW SAINSBURY'S SUPERSTORE: SELSDON, CROYDON, UK}

\section{Prologue}

In 2002, an opportunity became available to develop a Sainsbury's supermarket in Selsdon, Croydon, South London (see Figure 1). The site was adjacent to Selsdon High Street and comprised of a Local Authority car park, library and playing fields. The extent of the area was very limited and would only accommodate a supermarket with a $25,000 \mathrm{ft}^{2}$ sales area and a decked car park with just 245 spaces - given the likely level of trade and access to the High Street, about 350 spaces would have been the normal requirement. In-office analysis of the potential catchment showed that this was an underserved area in terms of supermarket provision and the demographics very much matched the Sainsbury customer profile. Theoretically, this was a prime opportunity but there were concerns regarding the degree to which sales would be affected by the constrained store size and parking. The site analysts were of the opinion that the site must be visited to understanding the key context-specific issues before in-office modelling commenced.

\section{Site visit findings: The site itself}

The visit highlighted the following issues about the site itself:

- The site was by a major crossroad and separated from the High Street by another, less busy road. At peak time there was traffic congestion at this junction with up to 50 cars backing up in each direction.

- The store would be very prominent and visible from both roads and was already a destination with the existing community centre and library.

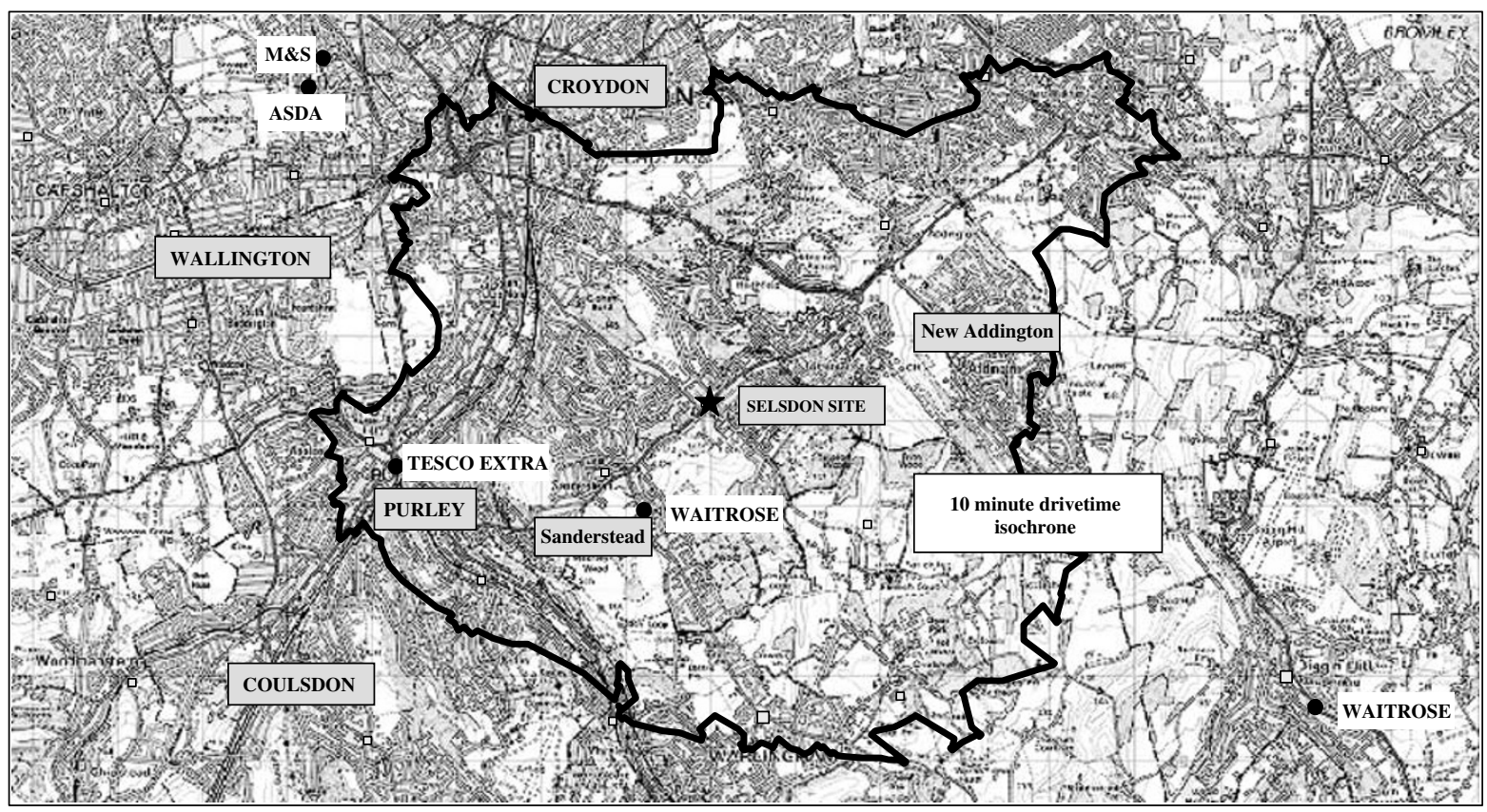

Figure 1: Selsdon catchment with 10 min drivetime isochrone (C) Crown Copyright Ordnance Survey. All rights reserved 
- Just behind the site was a large independent school with many supermarket trips potentially linked with the 'School run'.

- Although the High Street was the other side of the Old Farleigh Road, there was a pedestrian crossing and bus stops nearby.

- The High Street was very lively with virtually no vacant units.

- At the other end of the High Street was a Somerfield supermarket $\left(8,000 \mathrm{ft}^{2}\right)$. Standards in the store were poor and the range was focused on a top-up shop rather than a main supermarket. The store was served by a small car park with 45 spaces.

- The only other car parking was on-street pay and display and even off peak there were few vacant spaces.

\section{Site visit findings: The catchment}

- The catchment area showed a contrast of housing while Selsdon itself was an affluent outer London suburb with attractive mainly semi-detached housing built in the 1930s. Most houses had their own garages and drives with more than one garage.

- Located one mile to the south-west, Sanderstead was similar but with larger more exclusive houses and a higher proportion of detached houses. It was served by its own small high street and there was a planning consent for a small Waitrose.

- Located one mile to the north-east, Forestdale was a high density housing estate built during the 1960s, consisting of privately owned dwellings especially suited to the first time buyer.

- Located two miles to the east, New Addington was a post war council estate displaying high degrees of private ownership leading to significant redevelopment and refurbishment. There was a strong parade of small shops, a community centre and swimming pool.

- It was noted from the visit that all of the above were very distinct communities. Although within the $10 \mathrm{~min}$ driving time, the visit indicated that the store should attract trade strongly within Selsdon itself and where Selsdon stretched down to South Croydon and Purley. In contrast to the output of the gravity model, the analyst considered the store would be unlikely to trade strongly from Forestdale and New Addington which benefited from being served by the new Croydon Tramlink.

\section{The competition}

- The only competition in Selsdon was a Somerfield, which was effectively a convenience store. Waitrose had consent to open an $18,000 \mathrm{ft}^{2}$ store with just 100 surface spaces in Sanderstead but this would only serve the immediate community. More significantly, in Purley there was a 59,000 $\mathrm{ft}^{2}$ Tesco Extra with a 500-space surface car park and petrol filling station.

- Given its pre-eminence in the catchment, the Tesco store was visited on several occasions and was obviously very successful; clearly constrained by its size. However, the access into and out of the store was very difficult due to a congested one-way road system.

\section{Conclusions from the site visit and forecasting implications}

- The visit provided reassurance that the site was prominent, visible and well placed to serve the identified catchment. The micro environment was pleasant and no problems of security were evident.

- The presence of a school, quality shops and bus routes meant the store was well placed to pick up linked shopping trips.

- There was some concern about traffic congestion and access into and out of the car park. Strong recommendations were made about installing a traffic light junction with the right phasing. However, access issues would be no worse than the key competitor, Tesco.

- A key requirement was identified by the analyst to re-balance some of the predicted draw of 
trade within the catchment from the gravity model analysis subsequently undertaken in the office. This store was going to achieve a strong market share within Selsdon itself but the propensity to draw from surrounding communities would be challenging, with the exception of linked school trips. This was where the observations on the site visit led to clearly identifiable changes in the forecasting process. In particular, it is noteworthy that this was based on no real 'hard' data but the impression gained when visiting the site - similar to Clarke and Mackaness' findings concerning the benchmarking of decisions compared to previous analogous scenarios previously observed. ${ }^{64}$

- The visit was reassuring in suggesting that the constrained nature of the car parking was probably going to be less of a factor given the limited parking also offered by the competition.

- The site visit gave reassurance that developing a store here was a viable decision and directly influenced the geography of the forecast catchment.

\section{The outcome}

The store opened in June 2004 and traded just above expectation. Since the forecast, a Waitrose opened as expected in Sanderstead with little impact on the stores sales as predicted following the site visit. In December 2005, Tesco opened a $15,000 \mathrm{ft}^{2}$ mezzanine in its Purley store and have announced plans to redevelop the whole store to become the largest Tesco in the country. They have also announced plans to build a store in New Addington. The Somerfield in Selsdon has closed and is being redeveloped as an Aldi.

\section{CASE STUDY 2: FORECASTING A NEW SAINSBURY'S CONVENIENCE STORE IN HAYES, KENT}

\section{Background - Emphasising contextual knowledge}

The Selsdon case study clearly demonstrates the impact a site visit had on the ultimate sales estimate for a supermarket in leading the analyst to amend the modelled draw of trade. For a convenience store, the site visit actually forms the basis of the estimate itself. At a practical level, arguably a gravity model is less appropriate in the convenience store market due to the paucity of available data designed for analysis at such a microscale. ${ }^{65}$ The trade is largely noncar and often linked with a separate shopping trip; leading to the catchment being analysed in a half mile radii rather than a drivetime band. A regression model is the most common tool to predict trade for such a unit and was used in this instance in combination with a site visit that was carried out first.

Similar to forecasting supermarkets, the key drivers of convenience store trade are population and competition, but to a lesser degree. However, it is not just number of households but also the working population in the vicinity. 'Workers' population tends to exhibit a steeper distance decay from the site that reflects the limited time workers have before and after work as well as at lunchtimes. Unfortunately, workplace data are rarely detailed enough to explain its microgeography in relation to the store location.

Competition in the convenience market is extremely fragmented with a large number of small multiple and independent operators that are inadequately recorded in commercially available databases. Furthermore, data on pedestrian foottraffic are rarely available and when it does, is unlikely to reveal the characteristics of the consumers passing the site; they could be pensioners or city professionals. The importance of the site visit is also underlined in the need to understand the micro-location of the site: the visibility and prominence of the site, the presence of on-street parking (often referred to as 'stopability') and bus stops are just some of the factors that need to be established. The visit also determines whether the site has a 'good pitch' experience suggests that a few yards off the main retail area can reduce potential sales by half.

\section{The site}

- The site was first identified in 1999 and was located on a local shopping parade in Hayes, Kent, south-east England (see Figure 2). 


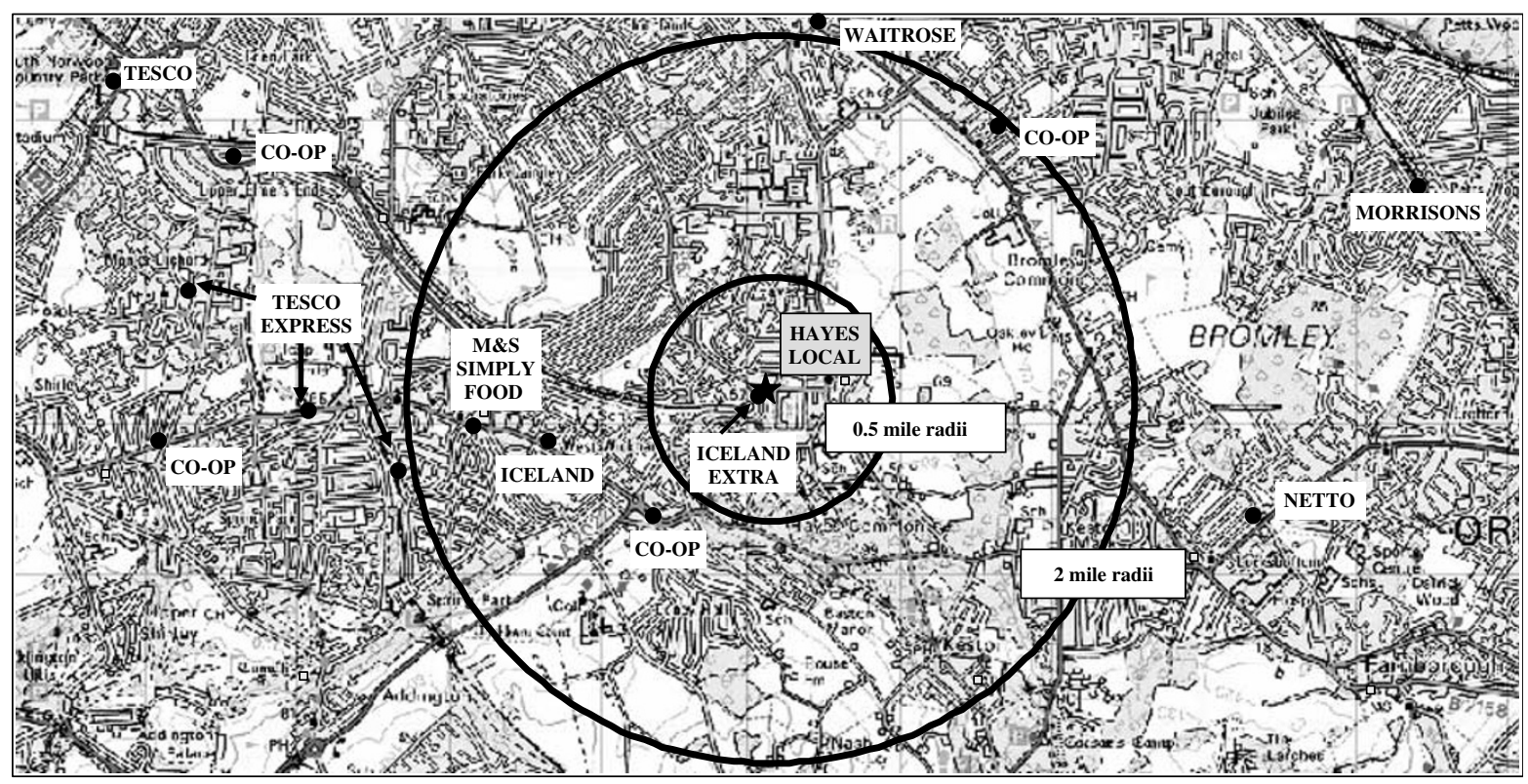

Figure 2: Hayes local catchment with 0.5 and 2 mile radii (C) Crown Copyright Ordnance Survey. All rights reserved

- Hayes shopping parade did not have a onestop shop supermarket, the nearest stores being two Sainsbury's superstores at a distance of 1.5 and 2.5 miles. The site was virtually opposite a small frozen food specialist retailer, Iceland, towards the northern end of the parade. At the other end of the parade about $150 \mathrm{~m}$ away was Hayes Railway Station, a southern terminus for a suburban line that runs to Charing Cross in Central London. Opposite the station was a small convenience store.

- The Sainsbury Local format requires a sales area of $3,000 \mathrm{ft}^{2}$ and the site visit showed that apart from Iceland and the site being reviewed, there were no other opportunities to establish a store of this size in the immediate area.

- There was on-street pay and display parking and a bus stop outside the site with a surface car park behind the shopping parade opposite.

- The site was visited on a weekday and Saturday morning and the footfall was typical compared to other shops within the Sainsbury portfolio and was predominately elderly. While the parade lacked some of the strong major national retailers, all of the stores were occupied and the units were well maintained and appeared to be flourishing.
- There were no other major footfall drivers such as schools or major businesses found during the visit. Employee data indicated that only 1,000 people worked within $1 / 4$ mile of the site, most of these being associated with local shops and services.

- Back at the office, the analysis of the catchment demographics provided a mixed picture: within one mile of the site there was only a population of 20,000 , although more affluent than Greater London and GB as a whole. From a positive perspective, pensioners accounted for about a third of the population and there was an over-representation of childless households. However, the proportion of single person households was below the average for Greater London and GB. Also of concern was the high car ownership (approx 80 per cent), given the lack of good parking at the site and the proximity of larger Sainsbury's stores on the edge of the localised catchment.

\section{The model inputs}

- A simple regression model was used that was based on the Sainsbury Local portfolio of the time. Most of the inputs were score based, 
which had a degree of subjectivity but was backed by clear definitions for each score category.

- The population score was quite low reflecting the limited population and the adverse characteristics. The working population also carried a low score reflecting both the data and the experience of the visit. However, the site scored strongly in terms of competition. Not only was there a lack of competition from the major operators but also independent stores were also poorly represented.

- Footfall received an 'average' score reflecting the counts undertaken during the two visits; however, there was a high score for prominence and visibility. 'Stopability' was quite good with on-street parking and a surface car park $100 \mathrm{~m}$ away.

- Footfall drivers scored modestly with the lack of strong adjacent operators, but the most difficult to score was 'Transport nodes'.

There was a bus stop outside but the issue was whether there would be any sales

benefit from being $150 \mathrm{~m}$ from the rail station. While there was little evidence of commuters passing the site, it was felt that the presence of a Sainsbury's Local would cause some consumers to divert to visit the store on their way home. This was a critical decision that stemmed from visit observations and had significant implications for forecast accuracy.

\section{The outcome}

The store opened in June 2000 and after a few months it became clear that it was trading at less than three quarters of its estimate. A review indicated that it was failing to draw commuters down from the rail station. In effect, the store acted solely a 'top-up shop' rather than a 'grab \& go' store for commuter traffic. This provided a lesson for future forecasts regarding the penalty of locating slightly 'off pitch' when attempting to capture commuter trade. Subsequent forecasts for the Local format have therefore considered this as a key issue to examine when carrying out site visits. Analysts are therefore encouraged to proactively amend in-store modelling when their experience 'on the ground' gives them cause to over-ride quantitative outputs.

The store was re-merchandised to target the top-up shopper and sales gradually increased over the following year. With an adjustment to the model to lower the transport node score, the store ultimately traded on forecast, giving reassurance that the model remained appropriate and that it was the scoring process derived from the misinterpretation of the catchment on the site visit that had caused the inaccuracy.

\section{CONTEXTUAL KNOWLEDGE AND THE DECISION-MAKING PROCESS}

The case studies presented in the above section serve as useful exemplars of the context-specific nature of store decision-making and that forecasting cannot be reduced exclusively to officebased processes and data management. In both cases, analysts observed issues not represented in their in-office data or models. In the Selsdon case, the analyst was able to amend the modelled data following experience of the catchment. In the second case, at Hayes, the analyst misinterpreted the impact of being 'off-pitch' and incorrectly scored the transport variable within the regression model. However, in turn, lessons were learned and fed into the analysis of subsequent sites.

Although a well-developed knowledge base in combination with complex modelling ability is a rich resource, its potential for solving location forecasting issues can only be realised when it is appropriately invoked and intelligently used. ${ }^{66}$ Importantly, while much of the management literature is exploring issues of knowledge management, situational context and decisionmaking processes, ${ }^{67,68}$ the literature on retail location decision-making tends to focus on 'harder' and quantifiable knowledge, where known data are manipulated often at the aggregate level, almost as if the decisions are purely a matter of technical judgment. ${ }^{69}$ Indeed, as Alexander ${ }^{70}$ observes, 'we remain in danger of accepting a partial understanding of the strategic locational decision making process in which important cultural aspects are neglected' (p. 62). 
The conventional approach of business is to logically analyse which inevitably leads to the construction of 'process', or in this instance, 'modelling procedures', for employees to follow. Positively, this allows for replicability and best practice but:

In practice this means: the more information, the better;'cool and calm' strategic thinking should not be debased by feelings; efficient thought and behavior must be called upon to subjugate emotion; and good organizations manage employees' feelings out of the process. (Sadler-Smith and Shefy, ${ }^{71}$ p. 77 )

Our case studies have underlined though, that while the site visit generally provides data that supports in-office analysis, it can also allow analysts to uncover issues that are sometimes difficult to represent in models (see Table 3).

At an elementary level the site visit may provide more accurate data to enter into models such as traffic flows or pedestrian footfall, thereby supporting the in-office analysis. In more complex cases, the site visit exposes contextual problems that cannot always be captured in objective functions and therefore solved as structured problems within models. As Longley ${ }^{72}$ argues, 'digital representations of the real world within GIS will almost always necessarily remain partial and incomplete' (p. 108). Moreover, for Fisher and Unwin ${ }^{73}$ :

the traditional mathematical conception of space is widely perceived as constituting the dominant influence in providing a theoretical basis for
GIScience, yet it falls dramatically short of the kind of rich and highly structured conceptions of space that are required to do justice to all the concerns of either the natural or social sciences. (p. 8)

The very human agency that models may have the effect of limiting may be the crucial piece of information that ensures an accurate forecast (as with the Hayes case study).

\section{Modelling 'process' and knowledge integration}

There is a fundamental challenge in integrating observations collected on the site visit into a form that can be integrated into technical assessment techniques. To do so may require a change in the nature of that knowledge to be compatible with processing by conventional modelling techniques or 'expert systems'. Clearly some observations on the site visit are easier to convert into codified knowledge than others. As Table 4 suggests, the collection of quantitative or codified data such as traffic flows are relatively easily integrated into models. In contrast, what we regard as 'hybrid' knowledge (in between codified and tacit knowledge), such as a field observation of the visibility of a site or competitor store may be interpreted in the field and some conclusions made by the analyst, but for this knowledge to become useful and included within the formalised forecasting technique (eg a spatial interaction model), this must be codified, possibly with visibility graded on a numerical scale within computer code embedded within the model.

Table 3: Benefits of the site visit

\begin{tabular}{|c|c|c|c|c|}
\hline $\begin{array}{l}\text { Role of site } \\
\text { visit }\end{array}$ & $\begin{array}{l}\text { Techniques to } \\
\text { employ 'on site' }\end{array}$ & $\begin{array}{l}\text { Calibration of spatial } \\
\text { interaction models }\end{array}$ & $\begin{array}{l}\text { Collect data difficult to express } \\
\text { in spatial interaction models }\end{array}$ & $\begin{array}{l}\text { Other benefits of the } \\
\text { site visit }\end{array}$ \\
\hline $\begin{array}{l}\text { Examples } \\
\text { of site visit } \\
\text { benefit }\end{array}$ & $\begin{array}{l}\text { Checklists } \\
\text { Experience/gut feel/ } \\
\text { experimental }\end{array}$ & $\begin{array}{l}\text { Road speeds } \\
\text { Competitor sizes } \\
\text { Competitor car park } \\
\text { (no of spaces) } \\
\text { Pedestrian flows } \\
\text { Traffic flows } \\
\text { Population affluence } \\
\text { versus database } \\
\text { Exact location of } \\
\text { competitors }\end{array}$ & $\begin{array}{l}\text { Visibility of site } \\
\text { Benefit/drawbacks of adjacent } \\
\text { retailing } \\
\text { Role of 'trade barriers' (eg } \\
\text { rivers, motorways) in customer } \\
\text { decision-making } \\
\text { 'Quality' of the competition } \\
\text { The 'feel' of the site } \\
\text { Ease of access of store } \\
\text { Type and structure of residential } \\
\text { catchment }\end{array}$ & $\begin{array}{l}\text { Aid in selection of suitable } \\
\text { analogue stores }\end{array}$ \\
\hline
\end{tabular}


Meanwhile, pure tacit knowledge, intuition and experience are rather more difficult to integrate and may have to be considered 'outside' of the formalised modelling process via some form of manual adjustment.

The paradox with quantitative decision-support systems is often that 'tacit knowledge has great strategic value but that it must be codified to exploit that value' (Coff et al., ${ }^{74}$ p. 454). For

Table 4: Types of knowledge and knowledge integration in the forecasting process

\begin{tabular}{|c|c|c|}
\hline $\begin{array}{l}\text { Type of } \\
\text { knowledge }\end{array}$ & Example on site visit & $\begin{array}{l}\text { Difficulty to } \\
\text { integrate into } \\
\text { formalised } \\
\text { forecasting } \\
\text { process }\end{array}$ \\
\hline Tacit & $\begin{array}{l}\text { 'Feel' of the catchment } \\
\text { (eg quality of } \\
\text { residential area, litter, } \\
\text { etc) also based on } \\
\text { 'experience' }\end{array}$ & High \\
\hline Hybrid & Visibility of the site & $\begin{array}{l}\text { Medium (potential } \\
\text { to introduce } \\
\text { surrogate value } \\
\text { on a numerical } \\
\text { scale into model) }\end{array}$ \\
\hline Codified & $\begin{array}{l}\text { Calibrate models with } \\
\text { observed numerical } \\
\text { data (eg traffic flow, } \\
\text { store sales areas, etc). }\end{array}$ & Low \\
\hline
\end{tabular}

Tuomi $^{75}$ with such processes: 'important aspects of knowledge are sedimented into the structure of the measuring device' (p. 109). The risk with such a distillation process and reconversion of fieldbased knowledge to binary data is that we may somehow lose the very understanding and insight that made the tacit knowledge gleaned in the field so potentially beneficial. There is clearly a challenge to 'off the shelf' forecasting packages here to retain flexibility.

\section{The role of organisational context}

It is not just the 'usability' of the technique, but also how it is implemented within the retailer organisation and used in a practical context that is critical to success. ${ }^{76,77}$ There is a difference between 'knowledge' per se (in theory) and 'knowing as action' ${ }^{\text {'7 }}$ as knowledge management can only be understood in context, grounded in what people do to get their work done. ${ }^{7}$

The complexity of forecasting places huge importance on individual analysts to maintain a strong understanding of the techniques that they are using and therefore the impact and limitations of such data within the model. As part of this, there must be the ability for the analyst to make representations outside of the models if there are issues above and beyond the model's

Table 5: Knowledge conversion from the site visit and modelling interaction

\begin{tabular}{|c|c|c|}
\hline Action & $\begin{array}{l}\text { Reducing observations to data and } \\
\text { incorporating into modelling systems }\end{array}$ & Considering knowledge outside of the model \\
\hline Site visit & Observe, interpret and analyse the site & \\
\hline Knowledge generation & $\begin{array}{l}\text { Viewpoint formed from observation and } \\
\text { experience }\end{array}$ & \\
\hline Codification & $\begin{array}{l}\text { Reduce 'knowledge' to data to incorporate } \\
\text { into model (eg gravity or regression model) }\end{array}$ & $\begin{array}{l}\text { Do not incorporate into formal modelling process and } \\
\text { take action to amend forecast outside of the modelling }\end{array}$ \\
\hline Model & Computational procedure & \\
\hline Output & $\begin{array}{l}\text { Output from model. Interpretation and } \\
\text { analysis }\end{array}$ & \\
\hline Forecast & Determine numerical forecast & \\
\hline $\begin{array}{l}\text { Determine cash return } \\
\text { on investment }\end{array}$ & Determine profitability & \\
\hline Make decision & $\begin{array}{l}\text { Based on profitability but also broader } \\
\text { strategic perspectives }\end{array}$ & \\
\hline
\end{tabular}


understanding and interpretation - as occurred in the Selsdon case study with manual adjustments to the gravity model output and should have occurred in the Hayes example due to its slightly off pitch nature (see Table 5). As such, 'a combination of modelling and expert judgement is an important way of improving decision effectiveness' (Clarke et al., ${ }^{79}$ p. 267), but clearly it remains challenging to develop ways of integrating these knowledges together in the decision-making process.

\section{CONCLUSIONS AND FUTURE RESEARCH DIRECTIONS}

There are some key findings that this study has uncovered: first, and most simply, this paper underlines the fact that despite huge advances in the tools and assessment techniques of site appraisal, there is no substitute for the field visit and the observations across a range of spatial scales and times of day. While most observations dovetail into in-office decision-support systems, they may be more difficult to introduce into formal modelling. However, these observations or tacit knowledge can clearly contribute to more accurate forecasting and thereby reduce investment risk. As the long established location expert, David Rogers ${ }^{80}$ recently reflected:

Technology cannot replace thorough field analysis and good retail intuition - nor cultural understanding.... Too many site selection firms - on both sides of the Atlantic - mistakenly believe that the activity involves manipulating databases and models in a comfortable office. While being a great 'assist', location research technology is only as accurate as the data employed, and the judgments and care used to manage the process of application. (p. 64)

Highly quantitative models are only simplifications of reality and rarely account for all of the factors influencing a retail site, underlining the need to 'get out there'. While it may be tempting for retail organisations to 'replace' site research executives with a technologically advanced 'model', this is likely to prove a false economy. The location planning process is one where issues of geography, consumer behaviour, government planning regulation and retailer strategy collide. Interpretative techniques to understand this must be flexible and varied. Furthermore, the lifecycle of a model must be considered in the decision-making process. The more complex the model, the greater the inputs, and ultimately the greater the work required to keep those inputs up to date. This may mean that a technique that performs initially well may end up impractical and resource draining in the longer term. Unfortunately, there is no single assessment tool that provides the panacea to forecasting difficulties. Instead it is often an untidy combination of techniques - both from in-office modelling and from site visits - that will reassure the analyst that they are accurate in their estimates.

Secondly, it is essential that office-based models do not become 'black boxes', impervious to all but the most sophisticated statisticians and operational research (OR) specialists. ${ }^{81}$ Analysts are very active agents in the forecasting process and it is their understanding, interpretation and analysis skills that are underplayed in the literature to date. Indeed:

Knowledge management systems are not automatic data processing systems: knowledge management initiatives therefore easily fail if they are conceived as technology problems. The difficult thing, of course, is that knowledge management then requires a broad understanding of social, technical, and cognitive aspects of human organizations (emphasis added, Tuomi, ${ }^{82}$ p. 115).

For example, with the case study in Selsdon, Croydon, the analyst was empowered to restrict the draw of trade forecast by the gravity model following site visit observations, thereby leading to a more accurate forecast. The role of the analyst is very much one of fusing the 'art and science' of location forecasting. Forecasters need to understand how their models work, the nature of their outputs and therefore how to amend them in the light of situational and contextual site visit data. In the implementation process of new high-tech modelling solutions there is a key role for the consultants of retailers to clearly explain to analysts how the models work hence the importance to building relationships 
with such firms and ensuring good service is critical. ${ }^{83}$ For instance, 'there is no point in developing an advanced sales forecasting method that requires operation by a $\mathrm{PhD}$ in Statistics when the technique will, in fact, be administered by market analysts with far less academic training' (Rogers, ${ }^{84}$ p. 12).

Third, a principal challenge raised by these findings is resolving the conflict between codified knowledge analysed and interpreted by computational assessment techniques and systems 'in the office', and the tacit-based knowledges that are generated 'in the field'. While the strength of many of the latest highly technical techniques discussed is the highly formalised and structuring focus that they give to data management, this can also make the introduction of the tacit knowledge collected 'at site' more difficult to utilise. As such, 'technologies are never neutral: they embody values and make certain things possible, but not others' (Tsoukas and Mylonopoulos, ${ }^{85}$ p. S3). This challenge is common across all organisations as it is essential to ensure that knowledge management is empowered rather than imposed by managerial and procedural approaches. ${ }^{86}$

There is no reason why such flexibility cannot be introduced into store forecasting processes with the site visit and its observations forming a key part of the procedure, as occurred in the case studies. We need greater understanding of how different kinds of knowledge are balanced and mediated within forecasting and decision-making. Given that decision-support systems are focused on reducing risk and providing a return on investment, the site visit is notable as requiring very little capital expenditure but has the potential to provide considerable improvements in accuracy.

Clearly challenges are focused on the organisational structure of retail and consultancy firms as much as the individual analysts themselves and the techniques that they employ. Indeed, different expert communities within an organisation 'may hold conflicting belief systems and thus engender incongruent interpretations of a given item of knowledge, resulting in communication breakdown' (Hsiao et al., ${ }^{87}$ p. 1291). It is therefore essential to understand how these differing perspectives and narratives concerning knowledge management are played out. ${ }^{88}$ Contextual knowledge has to be sufficiently valued within the forecasting process even if it cannot be formally introduced within computational models that seem to provide 'validity' or 'truth'. This, in turn, must also be considered, valued and reflected within the site assessment literature as it is only when modelling is employed in context can we really evaluate its worth.

\section{Acknowledegments}

Any comments made in this paper are the responsibility of the authors and not necessarily of the organisations discussed. We thank J Sainsbury plc for permission to use the case study material. We also appreciate the constructive comments of Tony Hernandez, Andrew Alexander, Alan Hallsworth and two anonymous referees on earlier drafts of the paper. All errors or omissions are our own.

\section{References and Notes}

1 Birkin, M., Clarke, G. and Clarke, M. (2002) 'Retail Geography and Intelligent Network Planning', John Wiley, Chichester.

2 Guy, G. (1999) 'Exit strategies and sunk costs: The implications for multiple retailers', International Journal of Retail and Distribution Management, Vol. 27, No. 6, pp. 237-245.

3 Cohen, S. and Applebaum, W. (1960) 'Evaluating store sites and determining store rents', Economic Geography, Vol. 36, No. 1, pp. 1-35.

4 Guy, G. (1999) op. cit.

5 González-Benito, J. and González-Benito, O. (2005) 'The role of geodemographic segmentation in retail location strategy', International Journal of Market Research, Vol. 47, No. 3, pp. 295-316.

6 See Orr, J. (1996) 'Talking about Machines: An Ethnography of a Modern Job', Cornell University Press, Ithaca, NY.

7 Orlikowski, W. (2002) 'Knowing in practice: Enacting a collective capability in distributed organizing', Organization Science, Vol. 13, No. 3, pp. 249-273.

8 Barki, H. and Pinsonneault, A. (2005) 'A model of organizational integration, implementation effort, and performance', Organization Science, Vol. 16, No. 2, pp. 165-201.

9 Nonaka, I. (1994) 'A dynamic theory of organizational knowledge creation', Organization Science, Vol. 5, No. 1, pp. 14-37.

10 Nonaka, I. (1994) op. cit.

11 Hernandez, T., Bennison, D. and Cornelius, S. (1998) 'The organisational context of retail location decision making', Geojournal, Vol. 45, No. 4, pp. 295-308.

12 Jones, K. and Simmons, J. (1990) 'The Retail Environment', Routledge, London.

13 Nelson, R. (1958) 'The Selection of Retail Locations', FW Dodge Corp, New York. 
14 Rogers, D. and Green, H. (1979) 'A new perspective on forecasting store sales: Applying statistical models and techniques in the analog approach', Geographical Review, Vol. 69, No. 4, pp. 449-458.

15 Davies, R. (1977) 'Store location and store assessment research: The integration of some new and traditional techniques', Transactions of the Institute of British Geographers (New Series), Vol. 2, No. 2, pp. 141-157.

16 Breheny, M. (1988) 'Practical methods of retail location analysis: A review', in Wrigley, N. (ed.), 'Store Choice, Store Location and Market Analysis', Routledge, London, pp. 39-86.

17 Wrigley, N. (1988) 'Retail restructuring and retail analysis', in Wrigley, N. (ed.), 'Store Choice, Store Location and Market Analysis', Routledge, London, pp. 3-34.

18 Moutinho, L., Curry, B. and Davies, F. (1993) 'Comparative computer approaches to multi-outlet retail site location decisions', Service Industries Journal, Vol. 13, No. 4, pp. 201-220.

19 Morrison, J. L. (1994) 'The paradigm shift in cartography: The use of electronic technology, digital spatial data, and future needs', in Waugh, T. and Healey, R. (eds), 'Advances in GIS Research', Taylor and Francis, London, pp. 1-15.

20 Mendes, A. and Themido, I. (2004) 'Multi-outlet retail site location assessment', International Transactions in Operational Research, Vol. 11, pp. 1-18.

21 Hernandez, T. (2007) 'Enhancing retail location decision support: The development and application of geovisualisation', Journal of Retailing and Consumer Services, Vol. 14, No. 4, pp. 249-258.

22 Birkin, et al. (2002) op. cit.

23 Coates, D., Doherty, N., French, A. and Kirkup, M. (1995) 'Neural networks for store performance forecasting: An empirical comparison with regression techniques', International Review of Retail, Distribution and Consumer Research, Vol. 5, No. 4, pp. 415-432.

24 Kuo, R., Chi, S. and Kao, S. (2002) 'A decision support system for selecting convenience store location through integration of fuzzy AHP and artificial neural network', Computers in Industry, Vol. 47, pp. 199-214.

25 Birkin, et al. (2002) op. cit.

26 Dijst, M., Burrough, P. and Schot, P. (2005) 'Coping with uncertainties in integrative spatial planning', Environment and Planning A, Vol. 37, pp. 1331-1334.

27 Guy, C. and Bennison, D. (2007) 'Planning guidance and largestore development in the United Kingdom: The search for "flexibility", Environment and Planning A, Vol. 39, No. 4, pp. 945-964.

28 Wood, S., Lowe, M. and Wrigley, N. (2006) 'Life after PPG6: Recent UK food retailer responses to planning regulation tightening', The International Review of Retail, Distribution and Consumer Research, Vol. 16, No. 1, pp. 47-65.

29 Poole, R., Clarke, G. P. and Clarke, D. B. (2006) 'Competition and saturation in West European grocery retailing', Environment and Planning A, Vol. 38, pp. 2129-2156.

30 Pioch, E. and Byrom, J. (2004) 'Small independent retail firms and locational decision-making: Outdoor leisure retailing by the crags', Journal of Small Business and Enterprise Development, Vol. 11, No. 2, pp. 222-232.

31 Rogers, D. S. (1987) 'Shop location analysis', in McFadyen, E. (ed.), 'The Changing Face of British Retailing', Newman, London, pp. 74-83.

32 Hernandez, T. and Bennison, D. (2000) 'The art and science of retail location decisions', International Journal of Retail and Distribution Management, Vol. 28, No. 8, pp. 357-367.
33 Ibid.

34 ReVelle, C. and Eiselt, H. (2005) 'Location analysis: A synthesis and survey', European Journal of Operational Research, Vol. 165, pp. 1-19.

35 Dasci, A. and Laporte, G. (2005) 'A continuous model for multistore competitive location', Operations Research, Vol. 53, No. 2, pp. 263-280.

36 González-Benito, O. (2002) 'Overcoming data limitations for store choice modeling. Exploiting retail chain choice data by means of aggregate logit models', Journal of Retailing and Consumer Services, Vol. 9, pp. 259-268.

37 Kuo, et al. (2002) op. cit.

38 Rust, R. and Donthu, N. (1995) 'Capturing geographically localized misspecification error in retail store choice models', Journal of Marketing Research, Vol. 32, pp. 103-110.

39 Sakashita, N. (2000) 'An economic analysis of a convenience store location', Urban Studies, Vol. 37, No. 3, 471-479.

40 Birkin, et al. (2002) op. cit.

41 Rogers, D. S. (1992) 'Retail Location Analysis in Practice', Longman, Harlow.

42 Clarke, I., Horita, M. and Mackaness, W. (2000) 'The spatial knowledge of retail decision makers: Capturing and interpreting group insight using a composite cognitive map', International Review of Retail, Distribution and Consumer Research, Vol. 10, No. 3, pp. 265-285.

43 Fenwick, I. (1978) 'Techniques in store location research - A review and applications', Retail and Planning Associates Research Reports, PO Box 5, Corbridge, Northumberland, NE45 5AA.

44 Brown, S. (1994) 'Retail location at the micro-scale: Inventory and prospect', Service Industries Journal, Vol. 14, No. 4, 542-576.

45 Shields, M. and Kures, M. (2007) 'Black out of the blue light: An analysis of Kmart store closing decisions', Journal of Retailing and Consumer Services, Vol. 14, No. 4, pp. 259-268.

46 Jackson, P., del Aguila, R. P., Clarke, I., Hallsworth, A., de Kervenoael, R. and Kirkup, M. (2006) 'Retail restructuring and consumer choice 2 . Understanding consumer choice at the household level', Environment and Planning A, Vol. 38, No. 1, pp. 47-67.

47 Ibid.

48 See Miller, H. (2005) 'What about people in geographic information science?', in Fisher, P and Unwin, D. (eds), 'Re-Presenting GIS', John Wiley, Chichester, pp. 215-242.

49 Wood, S. and Browne, S. (2007) 'Convenience store location planning and forecasting - A practical research agenda', International Journal of Retail and Distribution Management, Vol. 35, No. 4, pp. 233-255.

50 Applebaum, W. (1965) 'Measuring retail market penetration for a discount food supermarket - A case study', Journal of Retailing, Vol. 41, pp. 1-15.

51 Applebaum, W. (1966) 'Methods for determining store trade areas, market penetration, and potential sales', Journal of Marketing Research, Vol. 3, pp. 127-141.

52 Bowlby, S., Breheny, M. and Foot, D. (1985) 'Store location: Problems and methods 4: Local site and store evaluation issues', Retail and Distribution Management, Vol. 2, March/April, pp. 40-44.

53 Cohen and Applebaum (1960) op. cit.

54 Rogers (1992) op. cit.

55 Snow, W. and Scott, K. (1984) 'Site appraisals', in Davies, R. and Rogers, D. (eds), 'Store Location and Store Assessment Research', John Wiley, Chichester, pp. 215-231. 
56 Tinworth, A. (2005) 'Let's find out where it's at', Estates Gazette, Issue 540, 10th August, 2005.

57 Wolfe, D. (2005) '10 common mistakes in site modeling', MapInfo Magazine, Vol. 9, No. 1, pp. 9-11.

58 Ibid.

59 Clarke, et al. (2000) op. cit.

60 Clarke, I. and Mackaness, W. (2001) 'Management "intuition": An interpretative account of structure and content of decision schemas using cognitive maps', Journal of Management Studies, Vol. 38, No. 2, pp. 147-172.

61 Clarke, I., Mackaness, W. and Ball, B. (2003) 'Modelling intuition in retail site assessment MIRSA: Making sense of retail location using retailer's intuitive judgments as support for decisionmaking', International Review of Retail, Distribution and Consumer Research, Vol. 13, No. 2, pp. 175-193.

62 Blattberg, R. and Hoch, S. (1990) 'Database models and managerial intuition: 50 per cent model +50 per cent manager', Management Science, Vol. 36, No. 8, pp. 887-899.

63 Rogers, D. S. (2005) 'Developing a location research methodology', Journal of Targeting and Analysis for Marketing, Vol. 13, No. 3, pp. 201-208.

64 Clarke, I. and Mackaness, W. (2001) op. cit.

65 Wood and Browne (2007) op. cit.

66 Armstrong, M., De, S., Densham, P., Lolonis, P., Rushton, G. and Tewari, V. (1990) 'A knowledge-based approach for supporting locational decisionmaking', Environment and Planning B, Vol. 17, pp. 341-364.

67 Hsiao, R-L., Tsai, S. D-H. and Lee, C-F. (2006) 'The problems of embeddedness: Knowledge transfer, coordination and reuse in information systems', Organization Studies, Vol. 27, No. 9 , pp. 1289-1317.

68 Sadler-Smith, E. and Shefy, E. (2004) 'The intuitive executive: Understanding and applying "gut feel" in decision-making', Academy of Management Executive, Vol. 18, No. 4, pp. 76-91.

69 Clarke, I. and Hallsworth, A. (1994) 'Interorganizational networks and location investment decisions', International Journal of Retail and Distribution Management, Vol. 22, No. 6, pp. 38-45.

70 Alexander, A. (1997) 'Strategy and strategists: Evidence from an early retail revolution in Britain', International Review of Retail, Distribution and Consumer Research, Vol. 7, No. 1, pp. 61-78.

71 Sadler-Smith, E. and Shefy, E. (2004) op. cit.

72 Longley, P. (2004) 'Geographical information systems: On modelling and representation', Progress in Human Geography, Vol. 28, No. 1, pp. 108-116.
73 Fisher, P. and Unwin, D. (2005) 'Re-presenting geographical information systems', in Fisher, P. and Unwin, D. (eds), 'Re-presenting GIS', John Wiley, Chichester, pp. 1-13.

74 Coff, R., Coff, D. and Eastvold, R. (2006) 'The knowledgeleveraging paradox: How to achieve scale without making knowledge imitable', Academy of Management Review, Vol. 31, No. 2, pp. 452-465.

75 Tuomi, I. (2000) 'Data is more than knowledge: Implications of the reversed knowledge hierarchy for knowledge management and organizational memory', Journal of Management Information Systems, Vol. 16, No. 3, pp. 103-117.

76 Simkin, L. (1996) 'Tackling barriers to effective implementation of modelling in retail marketing applications', The International Review of Retail, Distribution and Consumer Research, Vol. 6, No. 3, pp. 225-241.

77 Birks, D., Nasirin, S. and Zailani, S. (2003) 'Factors influencing GIS project implementation failure in the UK retailing industry', International Journal of Information Management, Vol. 23, pp. 73-82.

78 Cook, S. and Brown, J. (1999) 'Bridging epistemologies: The generative dance between organizational knowledge and organizational knowing', Organization Science, Vol. 10, No. 4, pp. 381-400.

79 Clarke, et al. (2000) op. cit.

80 Rogers, D. (2006) 'Location research planning: The need for less hype', European Retail Digest, Vol. 49, pp. 63-64.

81 Simkin (1996) op. cit.

82 Tuomi (2000) op cit.

83 Kitay, J. and Wright, C. (2004) 'Take the money and run? Organisational boundaries and consultants' roles', Service Industries Journal, Vol. 24, No. 3, pp. 1-18.

84 Rogers (1992) op. cit.

85 Tsoukas, H. and Mylonopoulos, N. (2004) 'Introduction: Knowledge construction and creation in organizations', British Journal of Management, Vol. 15, pp. S1-S8.

86 Compare with Armistead, C. and Meakins,, M. (2002) 'A framework for practising knowledge management', Long Range Planning, Vol. 35, pp. 49-71.

87 Hsiao, et al. (2006) op. cit.

88 Boland, R. and Tenkasi, R. (1995) 'Perspective making and perspective taking in communities of knowing', Organization Science, Vol. 6, No. 4, pp. 350-372. 